\title{
Evaluation of breast cancer awareness among female university students in Malaysia
}

\author{
Muhammad A. HADI, Mohamed A. HASSALI, Asrul A. SHAFIE, Ahmed AWAISU. \\ Received (first version): 15-Aug-2009 \\ Accepted: 11-Jan-2010
}

\begin{abstract}
${ }^{*}$
Breast cancer is the most common cancer and the leading cause of cancer death among women of all ethnic and age groups in Malaysia.

Objective: The objectives of this study were to evaluate the knowledge of breast cancer risk factors, symptoms and methods of screening among female university students and their perception towards the disease treatment outcomes.

Methods: A cross-sectional survey was conducted from February to March 2008 at Universiti Sains Malaysia. Two hundred participants from 10 randomly selected faculties were interviewed face to face by a trained pharmacist using a validated questionnaire. In addition to their demographic characteristics, participants were required to answer 22 questions concerning knowledge of breast cancer and five questions related to their perception of breast cancer management and treatment outcomes. Data were analyzed using SPSS version 15.

Results: The mean age of the respondents was $26.7(S D=1.9)$ years. The results showed that the vast majority of the female university students had inadequate knowledge of breast cancer. The mean total knowledge score of the students was $60.7 \%$. Indian students had significantly less knowledge of breast cancer compared to their Chinese and Malay counterparts $(p<0.05)$. However, more than two third of the students were aware of breast self examination (BSE) and clinical breast examination (CBE) recommendations. Furthermore, the students had positive perceptions towards the treatment outcomes of breast cancer.

Conclusion: This study has highlighted the need of a breast cancer awareness campaign, which should also stress the importance of early detection and reporting of breast cancer.
\end{abstract}

Keywords: Breast Neoplasms. Awareness. Breast Self-Examination. Malaysia.

\footnotetext{
*Muhammad A. HADI. BPharm, MPharm(Clinical). Department of Clinical Pharmacy, Faculty of Pharmacy, Universiti Teknologi MARA. Shah Alam. (Malaysia). Mohamed A. HASSALI. BPharm, MPharm(Clinical), PhD. Discipline of Social and Administrative Pharmacy, School of Pharmaceutical Sciences, Universiti Sains Malaysia. Penang (Malaysia).

Asrul A. SHAFIE. BPharm, PhD. Discipline of Social and Administrative Pharmacy, School of Pharmaceutical Sciences, Universiti Sains Malaysia. Penang (Malaysia). Ahmed AWAISU. BPharm, MPharm(Clinical), PhD research fellow. Discipline of Clinical Pharmacy, School of Pharmaceutical Sciences, Universiti Sains Malaysia. Penang (Malaysia).
}

\author{
EVALUACIÓN DEL CONOCIMIENTO \\ SOBRE CÁNCER DE MAMA ENTRE \\ ESTUDIANTES UNIVERSITARIAS EN \\ MALASIA
}

\section{RESUMEN}

El cáncer de mama es el cáncer más común y la mayor causa de muerte entre jóvenes de todos los grupos étnicos y edad en Malasia.

Objetivo: Los objetivos de este estudio fueron evaluar el conocimiento sobre los factores de riesgo de cáncer de mama, los síntomas y los métodos de rastreo entre estudiantes universitarias y su percepción hacia los resultados del tratamiento de la enfermedad.

Métodos: Se realizó un estudio transversal de febrero a marzo e 2008 en la Universidad Sains Malaysia. Un farmacéutico entrenado entrevistó cara a cara a 200 participantes entre las 10 facultades aleatoriamente seleccionadas utilizando un cuestionario validado. Además, de sus características demográficas e les pidió que respondiesen 22 preguntas relativas al conocimiento del cáncer de mama y 5 relativas a su percepción sobre los resultados de su gestión y tratamiento. Los datos se analizaron utilizando el SPSS versión 15.

Resultados: La media de edad de los respondentes era de 26,7 (DE=1,9) años. Los resultados mostraron que la gran mayoría de las estudiantes universitarias tenían conocimientos inadecuados sobre el cáncer de mama. La media de puntuación total fue del $60,7 \%$. Las estudiantes indias tenían significativamente menos conocimiento que sus colegas chinas y malayas $(\mathrm{p}<0,05)$. Sin embargo, más de dos tercios de las estudiantes conocían las recomendaciones de auto-exámenes de cáncer de mama y de exámenes clínicos de mama. Incluso, las estudiantes tenían una percepción positiva sobre los resultados del tratamiento del cáncer de mama. Conclusión: Este estudio indicó la necesidad de una campaña de concienciación sobre el cáncer de mama, que también debería remarcar la importancia de la detección temprana y la comunicación del cáncer de mama.

Palabras clave: Neoplasias de mama. Conocimiento. Auto-examen de mama. Malasia. 


\section{INTRODUCTION}

Unlike developed nations, mortality associated with breast cancer among women remains a matter of serious concern in the developing nations. Malaysia is a multi-ethnic developing country with Malay, Chinese, and Indian ethnic groups being the most common. In Malaysia, breast cancer is the most common cancer among all ethnic groups and principal cause of cancer death in women, accounting for about $11 \%$ of all medical certified deaths. ${ }^{1}$ Although it appears that the incidence of breast cancer in Malaysia is lower than in developed countries, the difference may be attributable to the difficulties in getting accurate data and to under-reporting of cases. ${ }^{2}$ The age pattern showed a peak age-specific incidence rate for the 50-59 years of age, and then declined in the older women. ${ }^{3}$ The overall age-standardized incidence rate (ASR) was 46.2 per 100,000 women. The Chinese ethnic group had the highest incidence, with an ASR of 59.7 per 100,000 population followed by Indian: 55.8 and Malay: 33.9 per 100,000 population in 2003 . $^{3}$

Increased tumor size ${ }^{4}$ and poor long-term survival ${ }^{4,5}$ have been associated with delayed presentation of symptomatic breast cancer for three or more months from the first detection to the time of diagnosis and treatment. Approximately $20-30 \%$ of Caucasian women wait for at least three months before seeking help for breast cancer symptoms. ${ }^{6}$ In Malaysia, $50-60 \%$ of women present in Stage 3 and 4 with little or no benefit to be derived from any form of therapy. ${ }^{7}$ In developing countries, it is suggested that negative socio-cultural perception of breast cancer, strong beliefs in traditional medicine and perhaps strong religious beliefs are the main reasons for the delay in presentation. ${ }^{8,9}$ There are also data suggesting that factors related to women's knowledge and beliefs about breast cancer and its management may contribute significantly to medical help-seeking behaviors. ${ }^{10}$ Understanding the factors that influence patients' delay in seeking breast cancer treatment is therefore necessary to improve its treatment outcomes.

In Malaysia, breast cancer awareness studies are not well documented. The objectives of this study were to assess the knowledge of breast cancer among female university students at Universiti Sains Malaysia, Penang and their perception towards its treatment outcomes. This was the first part of a larger study which was targeted to assess breast cancer knowledge in the state of Penang, Malaysia.

\section{METHODS}

Study design and population

A cross sectional survey was conducted from 5th February to 15th March 2008 at Universiti Sains Malaysia, Penang, Malaysia. Penang is the eighth most populous state of Malaysia, with the Chinese ethnic group as the majority (42.6\%), followed by Malay $(41 \%)$ and Indian $(9.9 \%){ }^{11}$ Two hundred female students were recruited from ten randomly selected faculties/schools. Schools of Medicine and Pharmaceutical Sciences were excluded from the sampling frame in order to ensure unbiased student selection. Students with no personal history of breast cancer and the ability to understand the questionnaire were recruited for the study. Verbal informed consent was obtained from all the study participants

\section{Data collection}

Each participant was interviewed face-to-face by a trained researcher (MAH) using a validated questionnaire. The questionnaire was designed to obtain information on socio-demographic characteristics, knowledge, and perceptions of breast cancer. It was developed based on information drawn from the literature on risk factors, signs and symptoms, and common methods for early detection of breast cancer. Questions on the perception of breast cancer were adapted and modified from a study by Grunfeld et. al. ${ }^{12} \mathrm{~A}$ fivepoint Likert type scale (from strongly agree to strongly disagree) was used to elicit the perception of the women towards management and treatment outcomes of breast cancer. Developed in English language, the questionnaire was then translated into Bahasa Malay, which is the national language of Malaysia. The translation was validated using the standard forward and backward method. Face and content validation was done by two senior faculty members (MAAH and AAS), an oncologist (EMM) and an oncology pharmacist (TJK). The questionnaire was pre-tested on a convenient sample of 30 women (not included in final sample) drawn from the target population. In addition to questions on socio-demographic characteristics (age, level of education, monthly income, employment status and race), the final instrument had 27 items and was divided into four parts: general knowledge of breast cancer: 4 questions; knowledge of risk factors: 10 questions; knowledge of symptoms and screening tests: 8 questions; and perception towards the management and treatment outcomes of breast cancer: 5 questions. Participants were awarded one point for each correct response and zero points for each wrong or "do not know" response on items related to knowledge. The maximum score was 22 , since questions on perception of the management and treatment outcomes of breast cancer were not scored.

Data analysis

All data were analyzed using the Statistical Package for the Social Sciences (SPSS Inc., Chicago, IL) version 15.0 and Microsoft Excel. One-way ANOVA with Post Hoc Tukey HSD (Honestly Significant Difference: a Post Hoc analysis used for multiple comparisons in order to detect where differences exist between pair-wise groups) was used. The level of statistical significance was set at $p<0.05$. 


\section{RESULTS}

The mean age of the participants was 26.7 $(\mathrm{SD}=1.9)$ years (Table 1). Chinese ethnic group constituted the majority of the participants $(42 \%)$ followed by the Malay (36.5\%). Ninety-one percent of the respondents were undergraduate students.

\begin{tabular}{|l|c|c|}
\hline $\begin{array}{l}\text { Table 1: Sociodemographic } \\
\text { participants }\end{array}$ & variables of study \\
\hline Variables & $\mathrm{n}$ & $\%$ \\
\hline Age Mean (SD) & $26.7(1.9)$ & \\
$15-24$ & 86 & 43 \\
$25-34$ & 96 & 48 \\
$34-44$ & 18 & 9 \\
Ethnicity & & \\
Malay & 73 & 36.5 \\
Chinese & 84 & 42 \\
Indian & 33 & 16.5 \\
Others & 10 & 5 \\
Education level & & \\
Undergraduate & 182 & 91 \\
Post graduate & 18 & 9 \\
\hline
\end{tabular}

The overall mean total score of breast cancer knowledge was $13.97(\mathrm{SD}=3.71)$. There was a significant difference in mean total score of breast cancer knowledge among the ethnic groups (Table 2). Post-Hoc analysis (Tukey HSD) showed that Indians had significantly less knowledge as compared to Malay $(p=0.01)$ and Chinese $(p=0.02)$. However, there was no significant difference in the mean total score of Chinese and Malay ethnic groups $(p=0.99)$. shown in Table 4 revealed that about $27.4 \%$ of Chinese, $23.3 \%$ of Malay and only $18.2 \%$ of Indians had good knowledge of breast cancer. Less than $1 \%$ of the participants had very good knowledge and more than $30 \%$ of the study population had poor to very poor knowledge.

More than half of the participants $(62 \%)$ believed that woman can enjoy a good quality of life after receiving the treatment for breast cancer (Table 5). Only $21(10.6 \%)$ participants believed that breast cancer treatment is embarrassing.. However, more than $50 \%$ agreed that the treatment is a long and painful process.

\section{DISCUSSION}

Our findings confirmed the previous reports $8,13-15$ that the deficit in knowledge of symptoms and risk factors might be the reasons for the delayed presentation of breast cancer in developing countries. However, in developed nations where there is a diminution in mortality secondary to early detection and improved treatment modalities ${ }^{16,17}$, delayed presentation remains a problem for older women as seen in British ${ }^{12}$, American ${ }^{18}$, and Australian women. ${ }^{19}$ It has been reported that older adults should not be expected to seek medical help despite symptoms of disease, since these symptoms may not cause them any pain or affect their functioning. ${ }^{20}$ It is also noteworthy that women in the older age group, who are at increased risk of developing breast cancer lack sufficient knowledge about risk factors and symptoms of breast cancer.

\begin{tabular}{|c|c|c|c|c|c|c|}
\hline \multirow{2}{*}{$\begin{array}{l}\text { Knowledge } \\
\text { score }\end{array}$} & \multirow{2}{*}{$\begin{array}{l}\text { Max. } \\
\text { possible } \\
\text { score }\end{array}$} & \multicolumn{4}{|c|}{$\begin{array}{c}\text { Score } \\
\text { Mean (SD) }\end{array}$} & \multirow[b]{2}{*}{${ }^{*} p$-value } \\
\hline & & Malay & Chinese & Indian & Others & \\
\hline GK & 4 & $2.04(0.5)$ & $2.08(0.6)$ & $1.72(0.9)$ & $1.7(0.4)$ & 0.021 \\
\hline RF & 10 & $6.32(1.8)$ & $6.16(2.1)$ & $5.67(2.3)$ & $4.3(1.8)$ & 0.019 \\
\hline SS & 8 & $6.24(1.7)$ & $6.19(2.0)$ & $5(2.3)$ & $5.0(2.7)$ & 0.002 \\
\hline TS & 22 & $14.61(3.1)$ & $14.44(3.5)$ & $12.39(4.3)$ & $10.5(4.3)$ & 0.001 \\
\hline
\end{tabular}

Responses to some important questions are shown in Table 3. One hundred and eighty-one (90.5\%) of the participants wrongly believed that breast cancer was the leading cause of death in women and only $26(13 \%)$ correctly recognized the estimated lifetime risk of developing breast cancer to be 1 in 19 in Malaysian women. More than two-third of the study participants acknowledged family history, old age and cigarette smoking as potential risk factors for breast cancer. A vast majority of the study participants were unable to appreciate complex risk factors such as menopause after the age of 55 years $(68 \%)$, early onset of menses $(56.5 \%)$ and first child after the age of 30 years (35\%) are associated with breast cancer. Lump under armpit and pain in the breast region were the most frequently correctly identified symptoms of breast cancer. Surprisingly, 145 (72.5\%) study participants were aware about the recommendations for practicing breast self examination (BSE) and 144 $(72 \%)$ for clinical breast examination (CBE).

Further categorization of degree of knowledge using an arbitrary scoring scale, developed from literature,
In the present survey, most women respondents were aware of BSE and CBE, which is in contrast with the findings of another Malaysian study ${ }^{21}$, in which only $24.4 \%$ of women practiced BSE once a month and $18.4 \%$ had a Pap smear examination within the last three years. These variations can be explained by the difference in the study population as the latter study was conducted among electronic factory workers who usually come from lower socioeconomic status and less educated. The Malaysian Ministry of Health promotes the practice of monthly BSE for women above the age of 20 years, and annual CBE by medical or paramedical personnel. ${ }^{1}$ There is consistent evidence in the literature that $\mathrm{CBE}$ and mammography can reduce mortality due to early detection and treatment of breast cancer. $^{22}$ On the other hand, the effectiveness of BSE in reducing mortality is controversial, since clinical trials ${ }^{23,24}$ did not find any evidence that practicing it is beneficial in reducing mortality. Instead, higher rate of physician visits, increased level of anxiety and benign biopsies with consequent use of health resources were observed 
in women who were taught BSE. ${ }^{23}$ However, some scholars argue that practicing BSE make women more "breast aware" and consequently more liable to detect tumors since many breast tumors are discovered by women themselves. ${ }^{25}$ In developing countries like Malaysia where there is no nationwide population-based breast screening mammography program $^{7}$ due to limited resources, BSE is considered to be a simple, inexpensive, noninvasive, and non-hazardous intervention, which is not only acceptable, cost-effective and appropriate, but also encourages women to take an active responsibility in preventive health. ${ }^{1}$ among British women. ${ }^{12}$ Similarly, women in the British study were unable to appreciate complex risk factors such as early onset of menses and late menopause. Recognizing the whole range of breast cancer symptoms is essential for early selfdetection and treatment of breast cancer. Any intervention to improve knowledge of symptoms should also aim at limiting anxiety and ensuring medical facilities are not overloaded by helpseeking for benign symptoms. ${ }^{12}$

The vast majority of our study participants had correct beliefs about breast cancer management and its outcomes. They, however, had negative

\begin{tabular}{|c|c|c|c|c|c|c|}
\hline \multicolumn{5}{|l|}{ Item } & $\begin{array}{c}\text { Correct } \\
\mathrm{n}(\%)\end{array}$ & $\begin{array}{c}\text { Incorrect } \\
\mathrm{n}(\%)\end{array}$ \\
\hline \multicolumn{5}{|c|}{ General knowledge } & & \\
\hline \multirow{4}{*}{\multicolumn{5}{|c|}{$\begin{array}{l}\text { Only females are affected by breast cancer. } \\
\text { Breast cancer can be transmitted from one person to another. } \\
\text { Breast cancer is the leading cause of death in Malaysian women. } \\
\text { The estimated life time risk of developing breast cancer in Malaysian women is? }\end{array}$}} & $170(85.0)$ & $30(15.0)$ \\
\hline & & & & & $183(91.5)$ & $17(8.5)$ \\
\hline & & & & & $19(9.5)$ & $181(90.5)$ \\
\hline & & & & & $26(13)$ & $174(87)$ \\
\hline \multirow{2}{*}{\multicolumn{5}{|c|}{$\begin{array}{l}\text { Knowledge of breast cancer risk factors } \\
\text { Old age }\end{array}$}} & & \\
\hline & & & & & $145(72.5)$ & $55(27.5)$ \\
\hline \multicolumn{5}{|c|}{ Family history of breast cancer } & $183(91.5)$ & $17(8.5)$ \\
\hline & $165(82.5)$ & $35(17.5)$ \\
\hline \multicolumn{5}{|c|}{ Low fat diet } & $95(47.5)$ & $105(52.5)$ \\
\hline \multicolumn{5}{|c|}{ First child after the age of $30 \mathrm{yrs}$} & $130(65)$ & $70(35)$ \\
\hline \multicolumn{5}{|c|}{ Early onset of menses (Before the age of $12 \mathrm{yrs}$ ) } & $87(43.5)$ & $113(56.5)$ \\
\hline \multirow{2}{*}{\multicolumn{5}{|c|}{ Late menopause (after the age of $55 \mathrm{yrs}$ ) }} & $64(32)$ & $136(68.0)$ \\
\hline \multicolumn{4}{|c|}{ Use of oral contraceptive } & & $122(61)$ & $78(39)$ \\
\hline \multirow{2}{*}{\multicolumn{5}{|c|}{$\begin{array}{l}\text { Large breasts } \\
\text { breastfeeding }\end{array}$}} & $84(42)$ & $116(58)$ \\
\hline & & \multirow{2}{*}{\multicolumn{3}{|c|}{ Knowledge of breast cancer symptoms }} & $132(66)$ & $68(34)$ \\
\hline \multirow{2}{*}{\multicolumn{5}{|c|}{ Painless breast lump }} & $144(72)$ & $56(28)$ \\
\hline & & & & & $157(78.5)$ & $43(21.5)$ \\
\hline Lump under armpit & & & & & 149 (74.5) & $51(25.5)$ \\
\hline \multicolumn{5}{|c|}{ Change in breast shape } & $163(81.5)$ & $37(18.5)$ \\
\hline \multicolumn{5}{|c|}{ Pain in breast region } & $157(78.5)$ & $43(21.5)$ \\
\hline \multicolumn{5}{|c|}{ Dimpling of breast skin } & $117(58.5)$ & $83(41.5)$ \\
\hline \multicolumn{5}{|c|}{ BSE is recommended for females once a month } & $145(72.5)$ & $55(27.5)$ \\
\hline CBE is recomm & ided for females & a year & & & $144(72)$ & $56(28)$ \\
\hline \multicolumn{7}{|c|}{ Table 4: Status of breast cancer knowledge } \\
\hline \multirow[b]{2}{*}{ Total Score } & \multirow{2}{*}{$\begin{array}{l}\text { Status of } \\
\text { knowledge }\end{array}$} & \multicolumn{5}{|c|}{$\mathrm{n}(\%)$} \\
\hline & & $\begin{array}{l}\text { Malay } \\
\mathrm{n}=73\end{array}$ & $\begin{array}{c}\text { Chinese } \\
n=84\end{array}$ & $\begin{array}{l}\text { Indian } \\
\mathrm{n}=33\end{array}$ & $\begin{array}{l}\text { Others } \\
\mathrm{n}=10\end{array}$ & $\begin{array}{c}\text { Total } \\
\mathrm{N}=200\end{array}$ \\
\hline$\leq 7$ & Very poor & $2(2.7)$ & $4(4.7)$ & $5(5.9)$ & $3(30)$ & 14(10.8) \\
\hline $8-11$ & Poor & $11(15.2)$ & $15(17.8)$ & $10(30.3)$ & $3(30)$ & $39(20.4)$ \\
\hline $12-16$ & Moderate & $43(58.9)$ & $41(48.8)$ & $12(30.8)$ & $4(40.0)$ & $100(50.0)$ \\
\hline $17-20$ & Good & 17(23.3) & $23(27.4)$ & $6(18.2)$ & $0(0)$ & $46(18.0)$ \\
\hline$>20$ & Very Good & $0(0)$ & $1(1.2)$ & $0(0)$ & $0(0)$ & $1(0.8)$ \\
\hline
\end{tabular}

\begin{tabular}{|l|c|c|c|c|c|}
\hline Table 5: Perception towards breast cancer treatment and its outcomes & $\begin{array}{c}\mathrm{N} \\
\mathrm{SA}\end{array}$ & $\begin{array}{c}\mathrm{A} \\
\mathrm{n} \\
\text { Item }\end{array}$ & $\begin{array}{c}\mathrm{n} \\
\mathrm{n} \\
(\%)\end{array}$ & $\begin{array}{c}\mathrm{n} \\
(\%)\end{array}$ & $\begin{array}{c}\text { SDA } \\
\mathrm{n} \\
(\%)\end{array}$ \\
\hline A woman after receiving treatment for breast & 24 & 100 & 51 & 22 & 3 \\
cancer can enjoy a good quality of life. & $(12)$ & $(50)$ & $(25.5)$ & $(11)$ & $(1.5)$ \\
\hline The treatment for breast cancer is a long and & 23 & 83 & 63 & 29 & 2 \\
painful process. & $(11.5)$ & $(41.5)$ & $(31.5)$ & $(14.5)$ & $(0.5)$ \\
\hline Treatments for breast cancer are more helpful & 13 & 61 & 62 & 61 & 3 \\
to young people. & $(6.5)$ & $(30.5)$ & $(31.0)$ & $(30.5)$ & $(1.5)$ \\
\hline Treatment for breast cancer is embarrassing. & 2 & 19 & 39 & 90 & 50 \\
& $(1.3)$ & $(9.3)$ & $(19.3)$ & $(45)$ & $(24.9)$ \\
\hline Treatment of breast cancer results in loss of & 18 & 59 & 53 & 46 & 24 \\
physical beauty & $(9)$ & $(29.5)$ & $(26.5)$ & $(23)$ & $(12)$ \\
\hline SA= Strongly Agree; A= Agree; N= Neutral; DA=Disagree; SDA= Strongly disagree & & \\
\hline
\end{tabular}

Among the risk factor assessed in this study, family history of breast cancer was the most commonly identified risk factor, consistent with a recent crosssectional study of knowledge and belief conducted perception of breast cancer treatment by considering it to be a long-term and painful process.

The results of this survey suggest the need for educational programs as tools for improving the 
current knowledge of breast cancer, targeting women through the mass media and perhaps clinical settings. The programs should also emphasize the need for prevention of breast cancer by avoiding exposure to potential carcinogens such as frequent $\mathrm{X}$-rays exposure and cigarette smoke, and promoting healthy diets that are rich in fiber and contain less saturated fat, in addition to physical exercise. Television and radio broadcasts and distribution of leaflets should be used to disseminate the required information pertaining breast cancer. Although, television and radio appear to be better media to reach a wider audience, their benefits may be limited only to people who have access to them. Available data suggest that people prefer to learn about cancer-related issues from their doctors and health organizations. Therefore, proper counseling should be routinely given by healthcare providers within hospitals and clinics to improve breast cancer knowledge and in this setting leaflets may be an effective tool. The primary goal is to improve the survival rate by promoting early detection and medical help-seeking behaviors among women.
The study was conducted among the students of Universiti Sains Malaysia only and therefore might not be a representative of all universities across Malaysia. Furthermore, the current study was never designed to appraise the breast self examination technique of study participants.

\section{CONCLUSIONS}

Overall, the students had limited knowledge of risk factors and sign and symptoms of breast cancer. However, the students were aware of BSE and CBE guidelines. Furthermore, they had positive perception towards breast cancer treatment and its outcomes. The need of an intensive breast cancer awareness campaign which should also stress the importance of early detection and reporting is evident keeping in view the current status of breast cancer knowledge.

\section{CONFLICT OF INTEREST}

None declared. No external funding was obtained for this research project.

\section{References}

1. Narimah A, Rugayah HB, Tahir A, Maimunah AH. Breast Examination, National Health and Morbidity Survey 1996 Volume 20 Kuala Lumpur, Public Health Institute, Ministry of Health, Malaysia 1999.

2. Hisham AN, Yip CH. Spectrum of breast cancer in Malaysian women. World J. Surg. 2003; 27:921-923.

3. National Cancer registry. Second report on cancer incidence in Malaysia 2003; Available at www.radiologymalaysia.org/Archive/NCR/2ndNCR.pdf (Accessed 2007-09-15).

4. Richards MA, Smith $P$, Ramirez AJ, Fentiman IS, Rubens RD. The influence on survival of delay in the presentation and treatment of symptomatic breast cancer. Br J Cancer. 1999;79:858-864.

5. Rossi S, Cinini C, Di Pietro C, Lombardi CP, Crucitti A, Bellantone R, Crucitti F. Diagnostic delay in breast cancer: correlation with disease stage and prognosis. Tumori. 1990;76:559-562.

6. Richards MA, Westcombe AM, Love SB, Littlejohns P, Ramirez AJ. Influence of delay on survival in patients with breast cancer: a systematic review. Lancet. 1999;353:1119-1126.

7. Hisham AN, Yip CH. Overview of breast cancer in Malaysian women: A problem with late diagnosis. Asian J Surg. 2004;27:130-133.

8. Rashidi A, Rajaram SS. Middle Eastern Asian Islamic women and breast self-examination. Needs assessment. Cancer Nurs. 2000;23:64-70.

9. Rajaram SS, Rashidi A. Asian-Islamic women and breast cancer screening: a socio-cultural analysis. Women Health. 1999;28:45-48.

10. Odusanya OO, Tayo OO. Breast cancer knowledge, attitudes and practice among nurses in Lagos, Nigeria. Acta Oncol. 2001;40:844-848.

11. Department of Statistics. Malaysia Year Book of Statistics 2007. Kuala Lumpur: Department of Statistics Malaysia, 2007.

12. Grunfeld EA, Ramirez AJ, Hunter MS, Richards MA. Women's knowledge and beliefs regarding breast cancer. $\mathrm{Br} \mathrm{J}$ Cancer. 2002;86:1373-1378.

13. Usmani K, Khanum A, Afzal H, Ahmad N. Breast cancer in Pakistani women. J Environ Pathol Toxicol Oncol. 1996;15:251-253.

14. Harirchi I, Ebrahimi M, Zamani N, Jarvandi S, Montazeri A. Breast cancer in Iran: a review of 903 case records. Public Health. 2000;114:143-145.

15. Okobia MN, Bunker $\mathrm{CH}$, Okonofua FE, Osime U: Knowledge, attitude and practice of Nigerian women towards breast cancer: A cross-sectional study. World J Surg Oncol.. 2006; 4(11):1477-7819.

16. Peto R, Boreham J, Clarke M, Davies C, Beral V. UK and USA breast cancer deaths down $25 \%$ at ages $20-69$. Lancet. 2000;355:1822.

17. Ramirez AJ, Westcombe AM, Burgess CC, Sutton S, Johns LP, Richards MA. Factors predicting delayed presentation of symptomatic breast cancer: a systematic review. Lancet.1999;353:1127-1131.

18. Breslow RA, Sorkin JD, Frey CM, Kessler LG. American's knowledge of cancer risk and survival. Prev Med. 1997;26:170-177.

19. Paul C, Barratt A, Redman S, Cockburn J, Lowe J. Knowledge and perceptions about breast cancer incidence, fatality and risk among Australian women. Aust NZ J Public Health. 1999;23:396-400.

20. Ford G, Taylor R. The elderly as under consulters: a critical reappraisal. J R Coll Gen Pract. 1985;35:244-247. 
21. Chee HL, Rashidah S, K Shamsuddin Intan O. Factors related to the practice of breast self examination (BSE) and Pap smear screening among Malaysian women workers in selected electronics factories. BMC Women's Health 2003;3:3.

22. Dbameharha YA. Knowledge about breast cancer and mammography in breast cancer screening among women awaiting mammography. Turk J Med Sci. 2005;35:35-42.

23. Baxter N; Canadian Task Force on Preventive Health Care. Preventive health care, 2001 update: should women be routinely taught breast self-examination to screen for breast cancer? CMAJ. 2001;164(13):1837-1846.

24. Thomas DB, Gao DL, Ray RM, Wang WW, Allison CJ, Chen FL, Porter P, Hu YW, Zhao GL, Pan LD, Li W, Wu C, Coriaty Z, Evans I, Lin MG, Stalsberg H, Self SG. Randomized trial of breast self-examination in Shanghai: final results. J Natl Cancer Inst. 2002;94(19):1445-1457.

25. Larkin M. Breast self-examination does more harm than good, says task force. Lancet. 2001;357:2109.

\section{Welcome to the $16^{\text {th }}$ ISPW!}
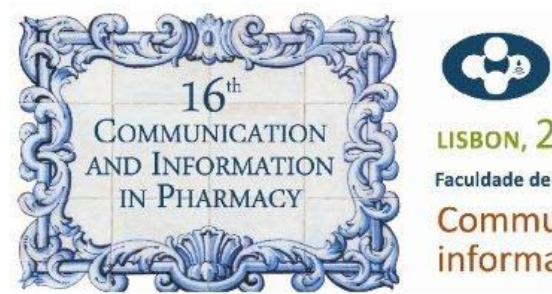

LISBON, 23rd $/ 26^{\text {th }}$ AUGUST 2010

Faculdade de Farmácia da Universidade de Lisboa

Communication and

information in pharmacy

This is a preliminary short announcement for the $16^{\text {th }}$ ISPW

Host Institution and Venue

Faculty of Pharmacy, University of Lisbon, Portugal

Dates

$23^{\text {rd }}$ to $26^{\text {th }}$ August 2010

Key note Speakers and further information soon to be announced at

www.ff.ul.pt/16ISPW

For any inquiries, please use the following email address: 161 SPW@ff.ul.pt

Hope to have you here in Summer 2010! 